\title{
Superheated steam injection in North Кенкияк shallow heavy oil reservoir
}

\author{
X. Zhao ${ }^{1 *}, \mathrm{P} . \mathrm{Gao}^{2}$ and $\mathrm{Y} . \mathrm{Wu}^{3}$ \\ ${ }^{1}$ Research Institute Petroleum Exploration and Development, Daqing Oilfields Company Limited, Heilongjiang \\ ${ }^{2}$ Petroleum Engineering Department, University of Wyoming, US \\ ${ }^{3}$ Research Institute Petroleum Exploration and Development, PetroChina Company Limited, Beijing, China.
}

Accepted 11 June, 2013

\begin{abstract}
This paper presents an integrated study on the superheated steam injection in the North Кенкияк Field, Kazakhstan. The methodologies cover investigation of mechanisms of superheated steam in recovery, lab experiment, and numerical simulation. The study indicates that the injection of superheated steam can cause rock wettability conversion which is favorable to recovery. The higher the heat enthalpy, the larger the specific volume and latent heat of vaporization of superheated steam would result in the better production and economic performance. The study result was further conformed in the pilot test. Field fulfillment is optimized and scheduled.
\end{abstract}

Key words: Superheated steam, shallow heavy oil reservoir, heatloss, reservoir simulation.

\section{INTRODUCTION}

Steam injection is an increasingly common method of extracting heavy crude oil. It is considered an enhanced oil recovery (EOR) method and is the main type of thermal stimulation of oil reservoirs. There are several different forms of technology, with the two main ones being cyclic steam stimulation and steam flooding. Both are most commonly applied to oil reservoirs, which are relatively shallow and which contain crude oils which are very viscous at the temperature of the native underground formation (Zhao et al., 2010; Gao and Towler, 2011).

The North Кенкияк oil field is a shallow conventional heavy oil field (Crude oil API: $21^{\circ}$ ), which is located in the South of Kazakhstan. The average depth of payzone is $310 \mathrm{~m}$. The initial oil saturation is $70.00 \%$. The reservoir has a high porosity of $29.00 \%$ and a relatively high permeability of $770.00 \mathrm{mD}$. The recovery energy of the primary production which began in 1966 mainly depended on an edge aquifer drive. Because of the quick invasion of aquifer, the water cut increased rapidly to
$80.00 \%$ in 1975 . The estimated primary recovery was only $21.60 \%$.

A pilot test of cyclic steam stimulation (CSS) with wet steam made a great success in 1975 . So far, $80 \%$ of its wells have been converted to CSS production wells. In order to further the performance of CSS, the pilot test of CSS with superheated steam began in 2006 and it exhibited even better results compared with wet steam injection (Gao et al., 2009; Zhao et al., 2010). The average oil rate was increased by $61.9 \%$; the cyclic production period was increased by 90 days, the average watercut was reduced by more than $10 \%$; and the residual oil saturation was minimized by $27.30 \%$.

Mechanism analysis by laboratory experiments and numerical simulation indicated that the superheated steam injection has the following advantages:

(1) Rock wettability conversion from oil-wet to water-wet by effect of superheated steam;

(2) More specific heat enthalpy of superheated steam 
Table 1. Relative permeability test results at different temperatures.

\begin{tabular}{lccc}
\hline \multirow{2}{*}{ Temperature } & \multicolumn{3}{c}{ Saturation $(\%)$} \\
\cline { 2 - 4 } & $\mathbf{S}_{\text {wi }}$ & $\mathbf{S}_{\text {oi }}$ & $\mathbf{S}_{\text {or }}$ \\
\hline Water flooding $\left(50^{\circ} \mathrm{C}\right)$ & 25.0 & 75.0 & 37.7 \\
Water flooding $\left(120^{\circ} \mathrm{C}\right)$ & 32.0 & 68.0 & 28.6 \\
Water flooding $\left(200^{\circ} \mathrm{C}\right)$ & 35.8 & 64.2 & 22.9 \\
Steam flooding $\left(200^{\circ} \mathrm{C}\right)$ & 37.9 & 62.1 & 19.2 \\
Super steam flooding & 40.6 & 59.4 & 16.8 \\
$\left(250^{\circ} \mathrm{C}\right.$, superheated degree: $\left.50^{\circ} \mathrm{C}\right)$ & & & \\
\hline
\end{tabular}

(hence less quantity needed by injecting the same heat enthalpy, which results in the lower watercut and higher oil rate);

(3) Larger specific volume and latent heat of vaporization of superheated steam (Zhao et al., 2010; Li et al., 2012).

Based on the detailed geological study and history match of the field production, the field-scale superheated steam injection scheme and production performance are planned and forecasted, which indicate that the plateau duration will last for 6 years with annual oil production of $0.363 \mathrm{MM}$ tons, and the oil recovery factor will be enhanced by $26.6 \%$ by injecting superheated steam.

\section{RECOVERY MECHANISM}

\section{Experimental investigation}

Relative permeability of oil and water, connate water saturation, residual oil saturation at different temperatures $(50,120,200$, and 200) are measured (Willman et al., 1961; Stone and Malcolm, 1985). The results seen in Table 1, indicate that:

(1) With the increase of temperature, the connate water saturation of the rock increases, and the wettability of the rock is gradually converted from oil-wet to water-wet. The connate water saturation at $200^{\circ} \mathrm{C}$ (water flooding) is $10.8 \%$ higher than that at $50^{\circ} \mathrm{C}$;

(2) With the increase of temperature, the residual oil saturation of waterflooding is decreased dramatically. The residual oil saturation at $200^{\circ} \mathrm{C}$ is $14.8 \%$ higher than that at $50^{\circ} \mathrm{C}$;

(3) The residual oil saturation for superheated steam flooding at $200^{\circ} \mathrm{C}$ is $3.7 \%$ lower than that of hot waterflooding;

(4) The residual oil saturation for superheated steam flooding at $250^{\circ} \mathrm{C}$ (superheated degree: $50^{\circ} \mathrm{C}$ ) is $2.4 \%$ lower than that of steam flooding at $200^{\circ} \mathrm{C}$. This means that compared with injecting the wet steam, the water mobility is reduced and the oil mobility is increased by injecting the superheated steam at the same temperature.

\section{Reservoir engineering analysis}

At the pressure of $4 \mathrm{MPa}$ and the temperature of $250^{\circ} \mathrm{C}$, the heat enthalpy, specific heat, and latent heat of vaporization of superheated steam at different superheated degree were measured and compared. And the wet steam with different steam quality was calculated. All these records can be seen in Table 2 .

According to the above measurements, it is can be concluded that when the steam injection pressure is $4 \mathrm{MPa}$ with injecting the same amount of steam, the steam volume for the superheated steam with the superheated degree of $10^{\circ} \mathrm{C}$ is 2.5 times that of the wet steam with steam quality of $40 \%$, which means that by injecting the same quantity of superheated steam, the contact area of steam with reservoir rock and liquid is evidently increased and the sweep efficiency, the reserve tapping efficiency would be greatly enhanced.

It can also been seen from Table 2 that with the increase of steam quality and overheated degree, the specific heat enthalpy, the specific heat, and the latent heat of vaporization increase simultaneously, therefore the region for steam to reduce the oil viscosity is increasingly larger, more and more oil with high mobility comes into the high-temperature regions with high oil relative permeability, and hence the good production performance of cyclic superheated steam injection can be expected (Falta et al., 1992; Li et al., 2012).

\section{Numerical simulation}

The CMG-STARS thermal simulator is utilized to model the superheated steam injection. At the pressure of 4 $\mathrm{MPa}$, both superheated steam (superheated degree: $50^{\circ} \mathrm{C}$ ) and wet steam with the same heat enthalpy were simulated (Table 3). The quantity of the wet steam with different steam quality and the superheated steam were calculated by their specific heat enthalpy.

It was indicated that under the condition of same heat enthalpy injection, by injecting the superheated steam, the water cut at the early stage was much lower than that by injecting wet steam; the initial oil production was much higher than that by injecting wet steam (Hossain, 1965; Jung, 1984; Ge and Ghassemi, 2008; Wu, 2009; Zhao et al., 2011). Therefore, the superheated steam injection took effect much sooner than wet steam injection during cyclic steam injection.

Compared to wet steam injection (Figures 1 and 2), the superheated steam injection effectively increases the steam chamber volume and reduces the region of oil viscosity. Therefore, the effect of oil viscosity reduction is more evident. The wettability of rock in a larger region converts from oil-wet to water-wet, which results in the better production performance of cyclic steam injection.

At the pressure of $4 \mathrm{MPa}$, the same quantity of superheated steam (superheated degree: $50^{\circ} \mathrm{C}$ ) and wet steam with different steam quality injected into the 
Table 2. Heat parameters comparison for wet steam and superheated steam (Compared with wet steam quality of $40 \%$ ).

\begin{tabular}{|c|c|c|c|c|c|c|c|}
\hline Heat parameter & $\begin{array}{l}\text { Steam } \\
\text { quality }\end{array}$ & $\begin{array}{c}\text { Specific heat } \\
\text { enthalpy } \mathrm{KJ} / \mathrm{Kg}\end{array}$ & $\begin{array}{c}\text { Incremental } \\
\text { (f) }\end{array}$ & $\begin{array}{c}\text { Specific } \\
\text { heat } \mathrm{m}^{3} / \mathrm{Kg} \\
\end{array}$ & $\begin{array}{c}\text { Incremental } \\
\text { (f) }\end{array}$ & $\begin{array}{c}\text { Latent heat of } \\
\text { vaporization } \mathrm{KJ} / \mathrm{Kg}\end{array}$ & $\begin{array}{c}\text { Incremental } \\
\text { (f) }\end{array}$ \\
\hline \multirow{8}{*}{ Wet steam } & 0.4 & 1772.6 & 0 & 0.0207 & 0 & 685.2 & 0 \\
\hline & 0.5 & 1943.9 & 0.1 & 0.0255 & 0.23 & 856.5 & 0.25 \\
\hline & 0.6 & 2115.2 & 0.19 & 0.0304 & 0.47 & 1027.8 & 0.50 \\
\hline & 0.7 & 2286.5 & 0.29 & 0.0352 & 0.70 & 1199.1 & 0.75 \\
\hline & 0.8 & 2457.8 & 0.39 & 0.0401 & 0.94 & 1370.4 & 1.00 \\
\hline & 0.9 & 2629.1 & 0.48 & 0.0449 & 1.17 & 1541.7 & 1.25 \\
\hline & 1.0 & 2800.4 & 0.58 & 0.0498 & 1.41 & 1713.0 & 1.50 \\
\hline & 10 & 2834.6 & 0.6 & 0.0518 & 1.51 & 1747.2 & 1.55 \\
\hline \multirow{4}{*}{$\begin{array}{l}\text { Superheated steam } \\
\text { (superheated degree, }{ }^{\circ} \mathrm{C} \text { ) }\end{array}$} & 20 & 2869.8 & 0.62 & 0.0536 & 1.60 & 1782.4 & 1.60 \\
\hline & 30 & 2902.0 & 0.64 & 0.0554 & 1.68 & 1814.6 & 1.65 \\
\hline & 40 & 2932.7 & 0.65 & 0.0572 & 1.77 & 1845.3 & 1.69 \\
\hline & 50 & 2962.0 & 0.67 & 0.0588 & 1.85 & 1874.6 & 1.74 \\
\hline
\end{tabular}

Table 3. Simulation results comparison for CSS with wet steam and superheated steam by same heat enthalpy injection.

\begin{tabular}{|c|c|c|c|c|c|}
\hline Heat parameter & $\begin{array}{c}\text { Steam quality } \\
(\%)\end{array}$ & $\begin{array}{c}\text { Cyclic time } \\
\text { (day) }\end{array}$ & $\begin{array}{c}\text { Cyclic steam } \\
\text { Injection (tons) }\end{array}$ & $\begin{array}{c}\text { Cyclic oil } \\
\text { production (tons) }\end{array}$ & $\begin{array}{c}\text { Oil steam } \\
\text { ratio (f) }\end{array}$ \\
\hline \multirow{4}{*}{ Wet steam } & 40 & 700 & 3716 & 1713.7 & 0.461 \\
\hline & 60 & 700 & 3114 & 1720.1 & 0.552 \\
\hline & 80 & 700 & 2680 & 1720.4 & 0.642 \\
\hline & 100 & 700 & 2352 & 1731.2 & 0.736 \\
\hline \multicolumn{2}{|c|}{ Superheated steam (superheated degree:50 $5{ }^{\circ} \mathrm{C}$ ) } & 700 & 2250 & 1756.3 & 0.781 \\
\hline
\end{tabular}

reservoir is simulated (Table 4).

Because of high steam quality and specific heat enthalpy of superheated steam, under the condition of same quantity of steam injection, the effect of oil viscosity reduction is more evident, the effective time of the latent heat is longer by superheated steam injection, which can be seen from the larger steam chamber volume (Zhang et al., 2010). Therefore, the superheated steam injection would effectively enhance the cyclic oil production and cyclic oil steam ratio.

\section{Pilot test}

At the end of 2006, a cyclic superheated steam stimulation pilot test was conducted in a section with 40 wells. The performance was agreeable. The statistics of the first cycle for cyclic superheated steam stimulation pilot test can be seen in Table 5. The average cyclic steam injection was 2237 tons which was $25.74 \%$ more than that in cyclic wet steam stimulation for the previous cycles (Figure 3 ). The average cyclic 


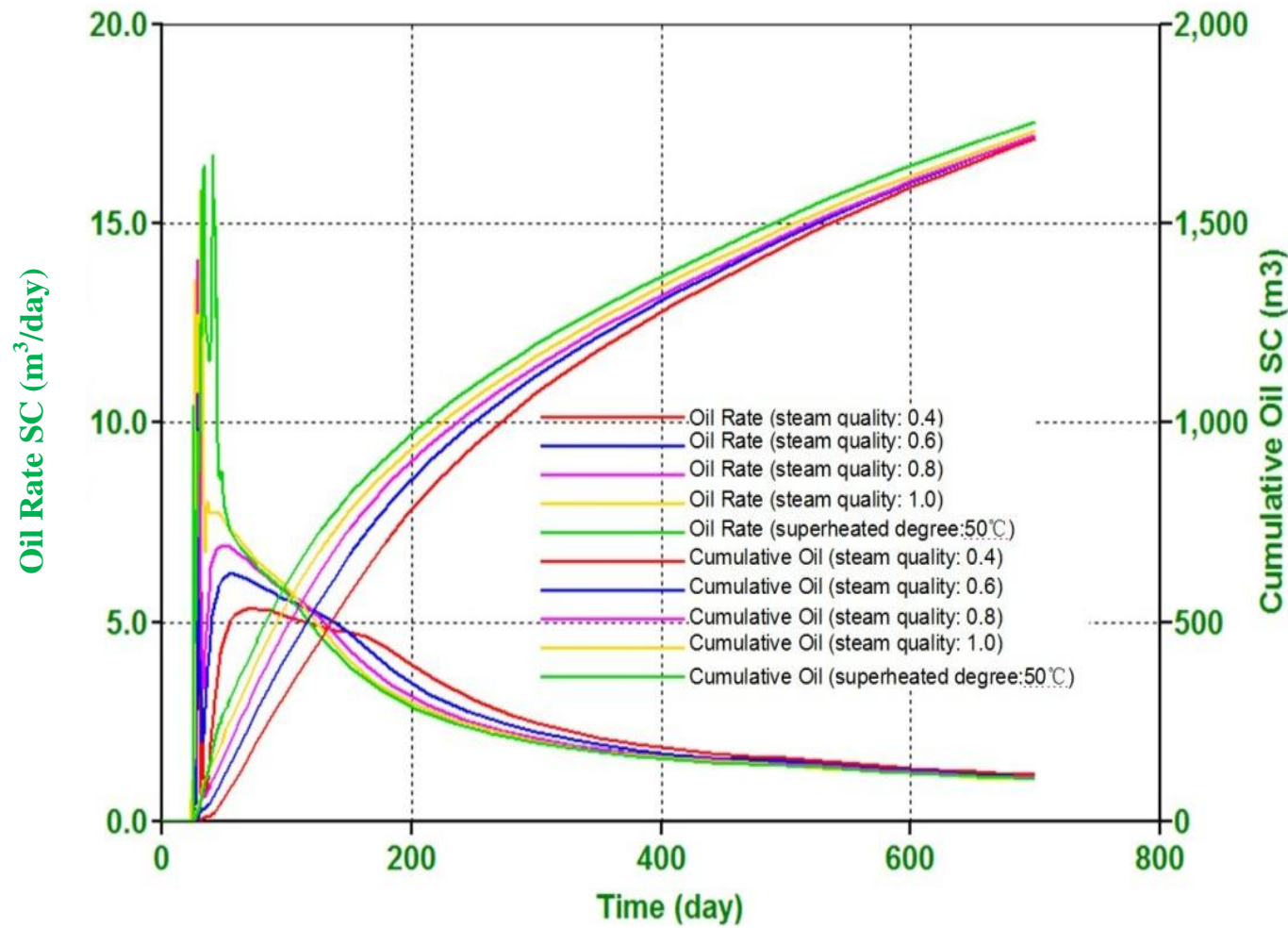

Figure 1. Production performance comparison for CSS with wet steam and superheated steam by same heat enthalpy injection.

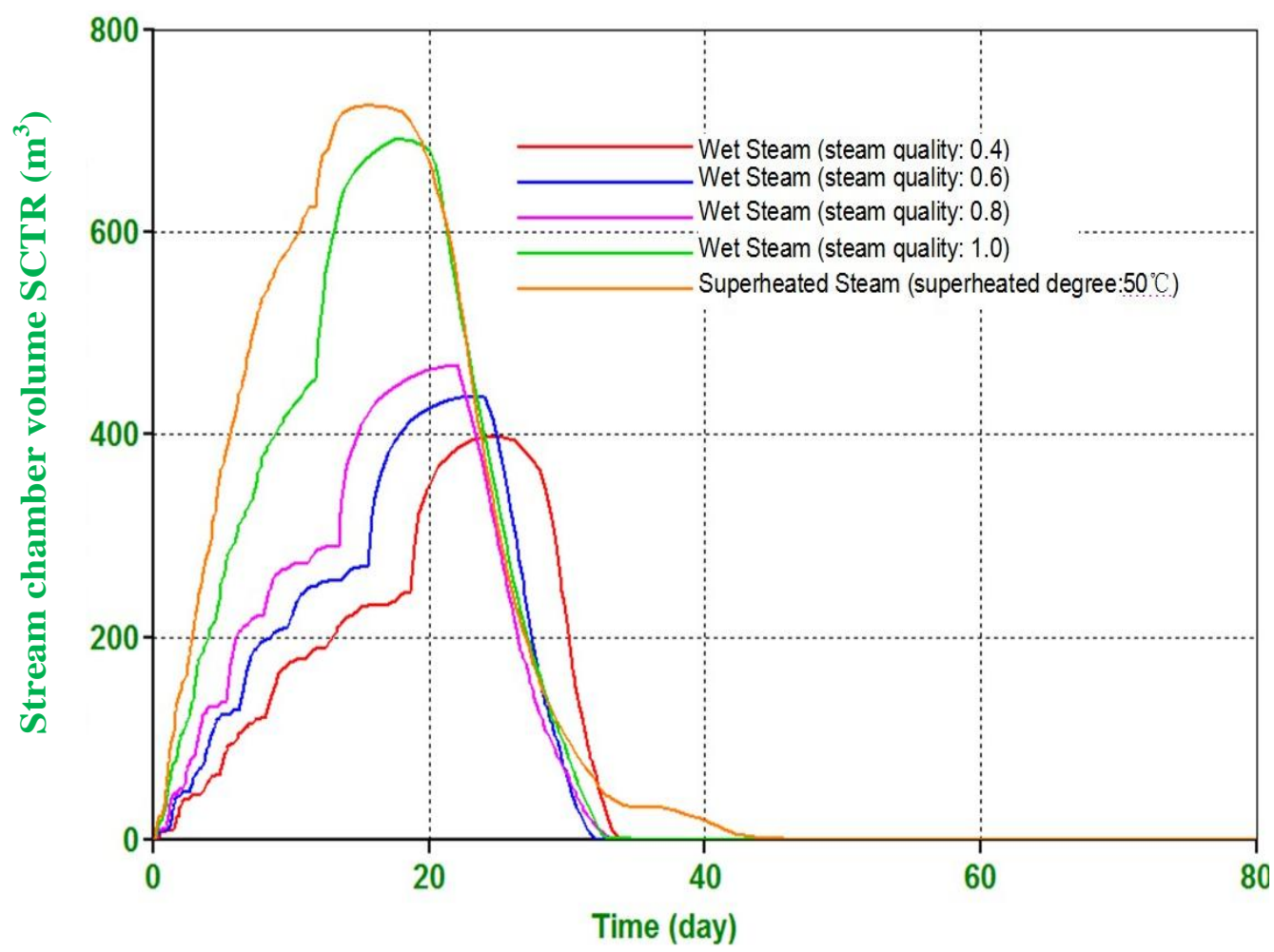

Figure 2. Steam chamber comparison for CSS with wet steam and superheated steam by same heat enthalpy injection. 
Table 4. Simulation results comparison for CSS with wet steam and superheated steam by same steam quantity injection.

\begin{tabular}{|c|c|c|c|c|c|}
\hline Heat parameter & Steam quality (\%) & $\begin{array}{c}\text { Cyclic time } \\
\text { (day) }\end{array}$ & $\begin{array}{c}\text { Cyclic steam } \\
\text { injection (tons) }\end{array}$ & $\begin{array}{c}\text { Cyclic oil production } \\
\text { (tons) }\end{array}$ & $\begin{array}{l}\text { Oil steam } \\
\text { ratio (f) }\end{array}$ \\
\hline \multirow{4}{*}{ Wet steam } & 40 & 700 & 2250 & 1594.5 & 0.7087 \\
\hline & 60 & 700 & 2250 & 1645.9 & 0.7315 \\
\hline & 80 & 700 & 2250 & 1697.3 & 0.7544 \\
\hline & 100 & 700 & 2250 & 1743.5 & 0.7749 \\
\hline \multirow{2}{*}{$\begin{array}{l}\text { Superheated } \\
\text { steam }\end{array}$} & Superheated degree: $50^{\circ} \mathrm{C}$ & 700 & 2250 & 1756.3 & 0.7806 \\
\hline & Superheated degree: $100^{\circ} \mathrm{C}$ & 700 & 2250 & 1773.4 & 0.7882 \\
\hline
\end{tabular}

Table 5. Comparison of average CSS performance (single well) with superheated steam and wet steam.

\begin{tabular}{|c|c|c|c|c|c|c|c|c|c|}
\hline $\begin{array}{l}\text { Cyclic } \\
\text { stimulation }\end{array}$ & $\begin{array}{l}\text { Cyclic steam } \\
\text { (tons) }\end{array}$ & $\begin{array}{l}\text { Cyclic liquid } \\
\text { (tons) }\end{array}$ & $\begin{array}{l}\text { Cyclic oil } \\
\text { (tons) }\end{array}$ & $\begin{array}{l}\text { Incremental oil (compared } \\
\text { with natural epletion) (tons) }\end{array}$ & $\begin{array}{c}\text { Average oil } \\
\text { rate (tons/day) }\end{array}$ & $\begin{array}{l}\text { Cyclic } \\
\text { OSR (f) }\end{array}$ & $\begin{array}{l}\text { Cyclic water and } \\
\text { steam ratio (f) }\end{array}$ & $\begin{array}{l}\text { Production and } \\
\text { injection ratio ( } \mathrm{f})\end{array}$ & $\begin{array}{l}\text { Cyclic time } \\
\text { (day) }\end{array}$ \\
\hline Superheated steam & 2237 & 11443 & 3123 & 1719 & 4.3 & 1.4 & 372 & 5.12 & 702 \\
\hline Wet steam & 1779 & 9179 & 1931 & 566 & 2.83 & 1.1 & 407 & 5.2 & 612 \\
\hline
\end{tabular}

period was 702 days. The average cyclic liquid production was 11443 tons with the average liquid rate of 14.9 tons per day (Figure 4).

The average cyclic oil production was 3123 tons with the average oil rate of 4.3 tons per day, which was $61.73 \%$ higher than that in cyclic wet steam stimulation of the previous cycles (Figure 5). The average water was dropped down by 10 to $69 \%$. The average oil steam ratio was 1.4 which was much higher than that in cyclic wet steam stimulation. The cyclic produced water-steam ratio was 3.72 which was 0.35 lower than that in cyclic wet steam stimulation (Figure 6).

The production performance of superheated steam CSS and wet steam CSS of typical wells above indicate that during early stage of production by wet steam CSS, the water cut is very low, but it increases sharply at the end of the cycle, while after superheated steam CSS, the water cut reduced evidently; the liquid rate remains similar to that at wet steam CSS stage, and the oil rate increase dramatically, consequently, the production performance of superheated steam CSS is much better than wet steam CSS.

\section{Fulfillment scheme}

\section{Superheated degree analysis}

Well heat loss model was employed in the simulation model. The parameters used are listed below; the depth that the super steam can reach is simulated for two cases (Table 6):

Case 1: Heat-insulated tubing used. Case 2: Conventional tubing used.
The simulation results indicate that by using heatinsulated tubing, the wet steam with $40 \%$ quality can reach the depth of $1689 \mathrm{~m}$, while the superheated steam (superheated degree: $50^{\circ} \mathrm{C}$ ) with superheated status can reach the depth of $902 \mathrm{~m}$. If using conventional tubing, the wet steam with $40 \%$ quality can reach the depth of $816 \mathrm{~m}$, while the superheated steam with superheated status can reach the depth of $580 \mathrm{~m}$ (Figure 7), which means that the superheated steam can maintain the superheated status in the near wellbore area, and the simulation result shows that the maximum radius of the super steam chamber can reach $3 \mathrm{~m}$.

\section{Production and injection parameters optimization}

Based on the detailed geological study and history 
Oil viscosity distribution ( $Q$ end of soak time)

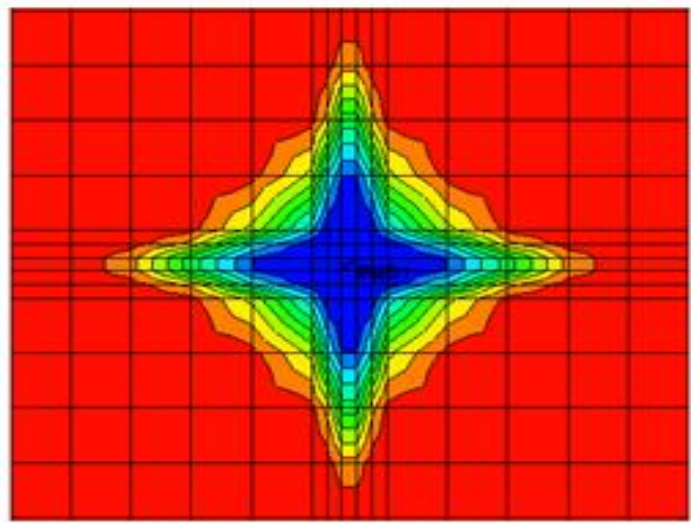

Wet steam (quality: $100 \%$ )

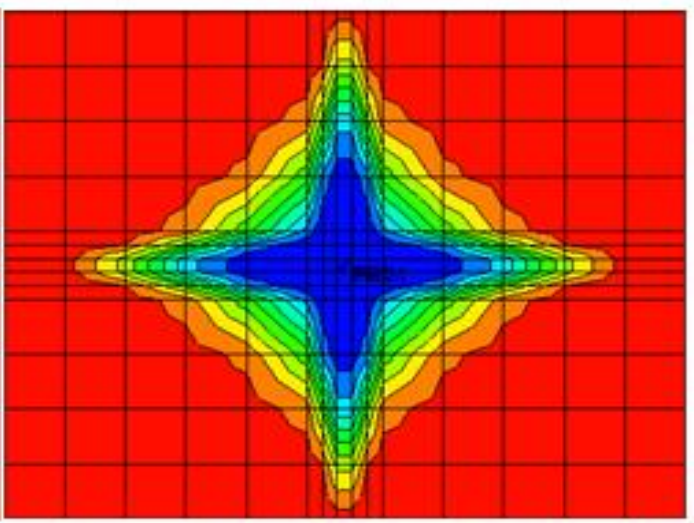

Super heated steam (superhsated

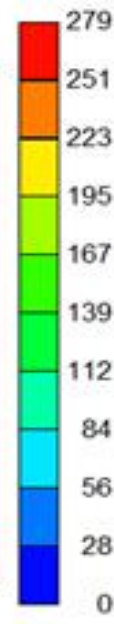

Steam quality distribution ( $Q$ end of soak time; DX, DY $=5 \mathrm{~m}$ )
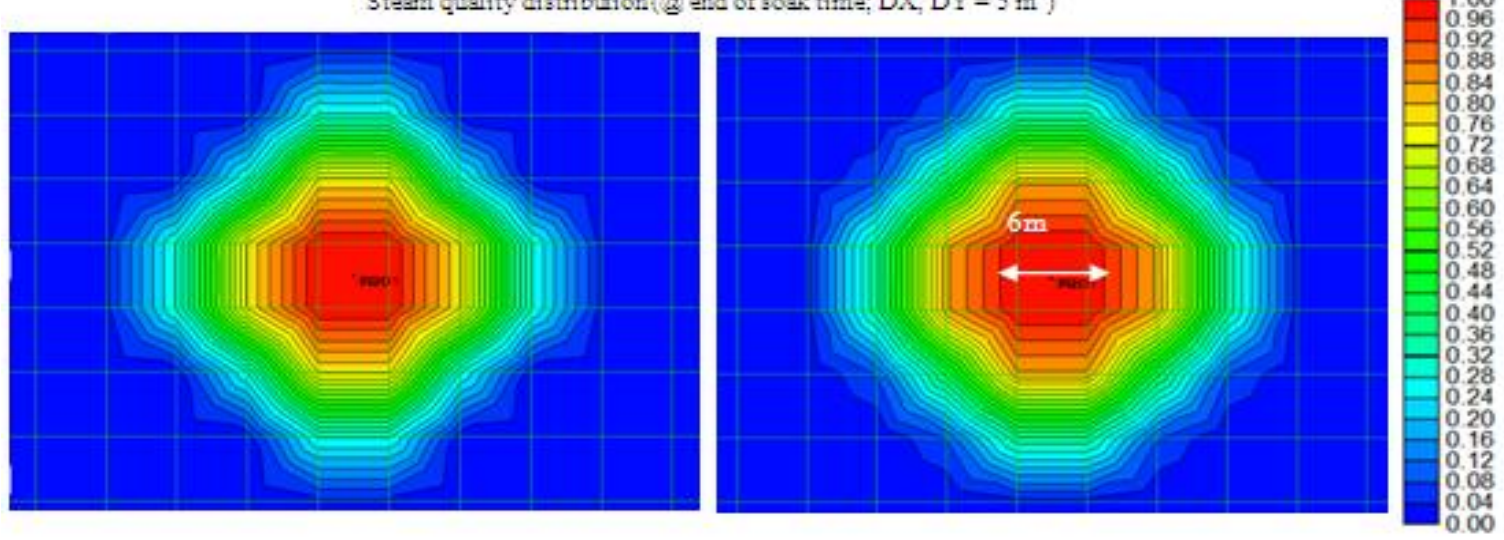

Figure 3. Oil viscosity distribution and steam chamber distribution for CSS with wet steam and superheated steam by same heat enthalpy injection.

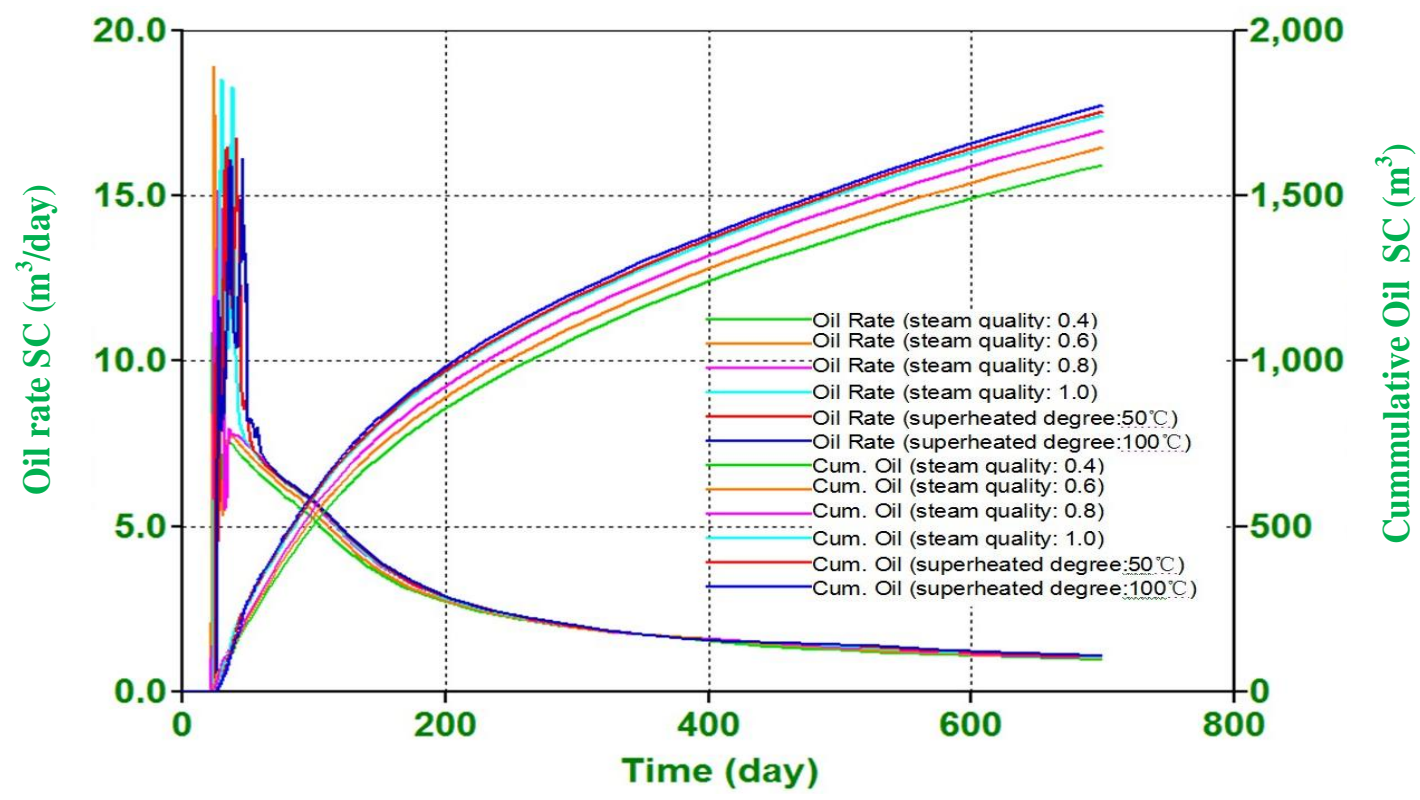

Figure 4. Production performance comparison for CSS with wet steam and superheated steam by same steam quantity injection. 


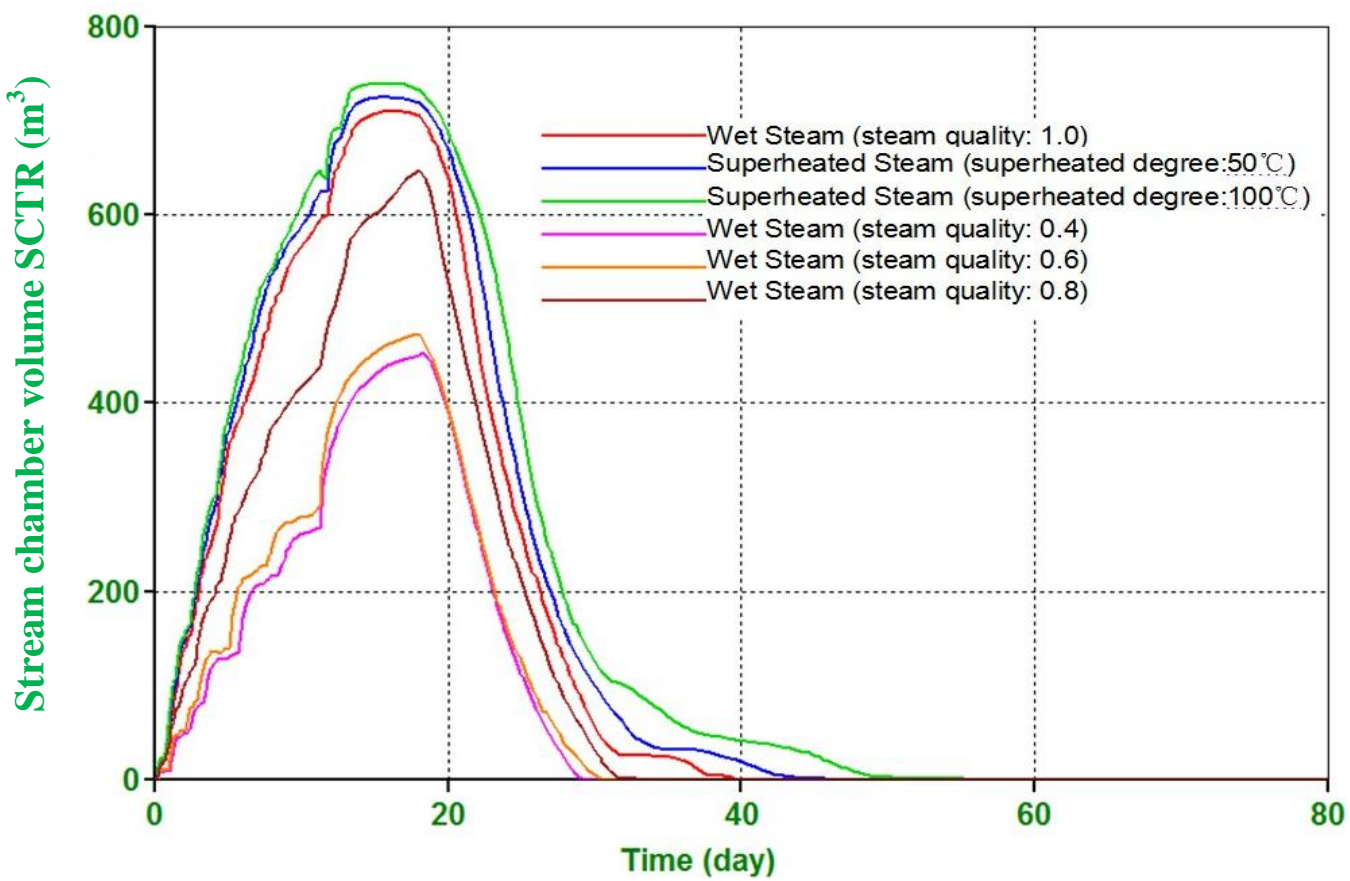

Figure 5. Steam chamber comparison for CSS with wet steam and superheated steam by same steam quantity injection.

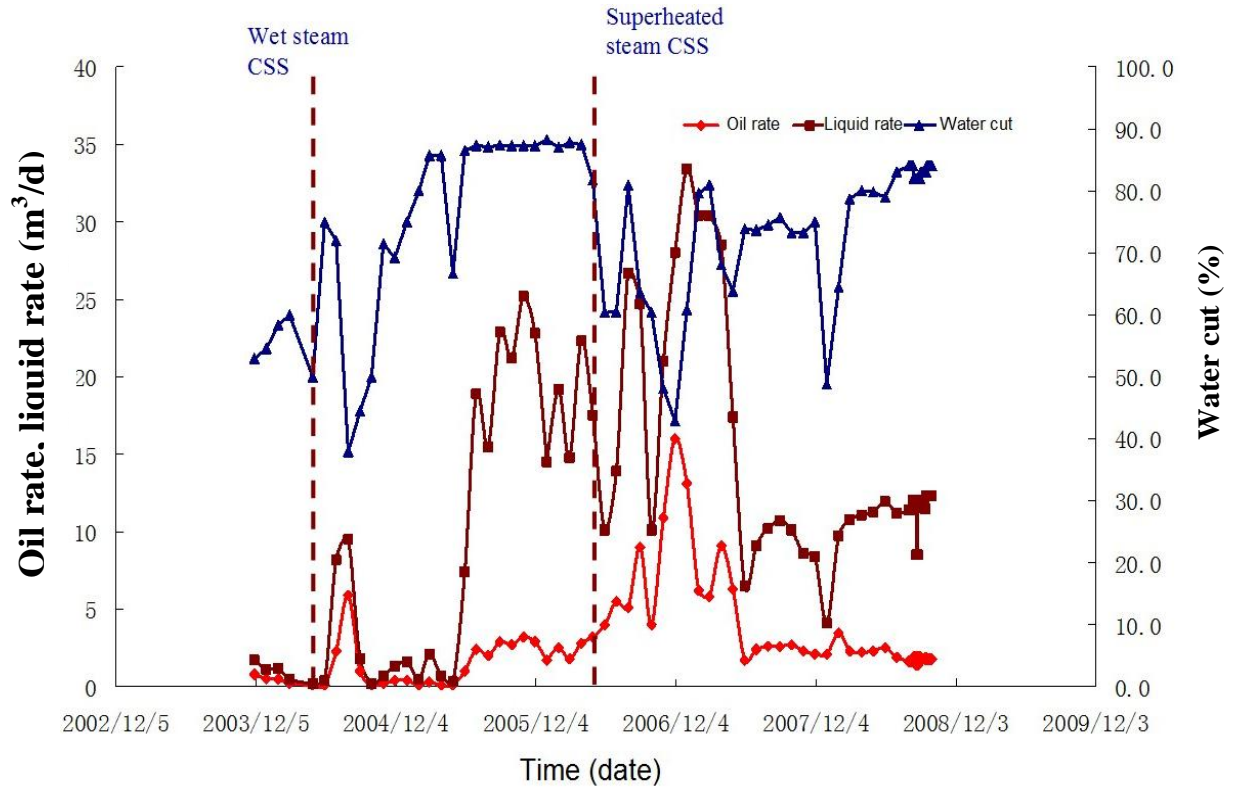

Figure 6. Comparison for CSS with wet steam and superheated steam (Well 61054).

Table 6. Parameters used in heat loss simulation.

\begin{tabular}{lllc}
\hline Wellhead temperature & $300^{\circ} \mathrm{C}$ & Inner radius of casing & $177.8 \mathrm{~mm}$ \\
Injection pressure & $3.5 \mathrm{MPa}$ & Inner radius of tubing & $73 \mathrm{~mm}$ \\
Injection rate & 8 tons/hour & Outer radius of tubing & $88.9 \mathrm{~mm}$ \\
\hline
\end{tabular}




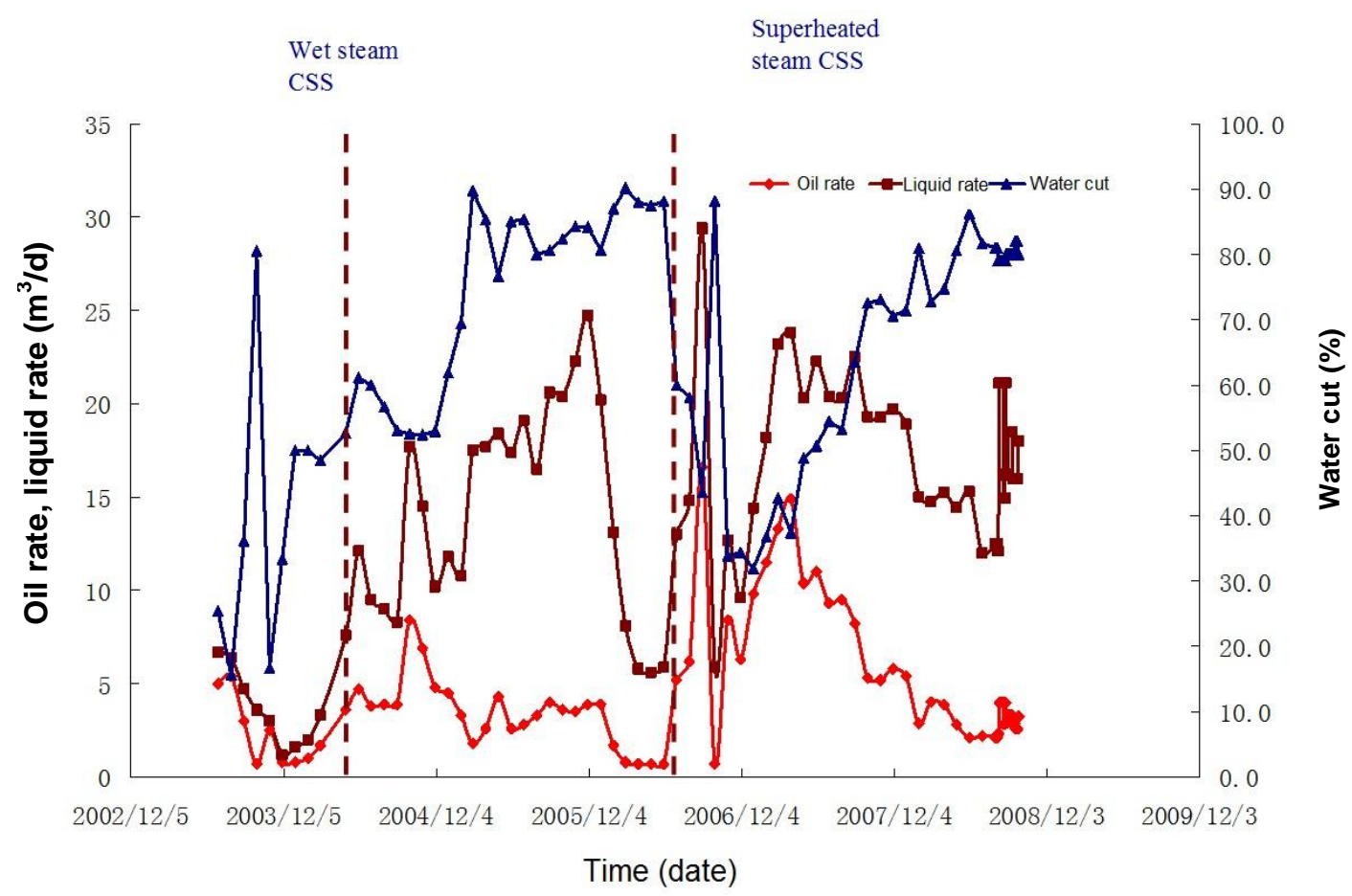

Figure 7. Comparison for CSS with wet steam and superheated steam (Well 61046).

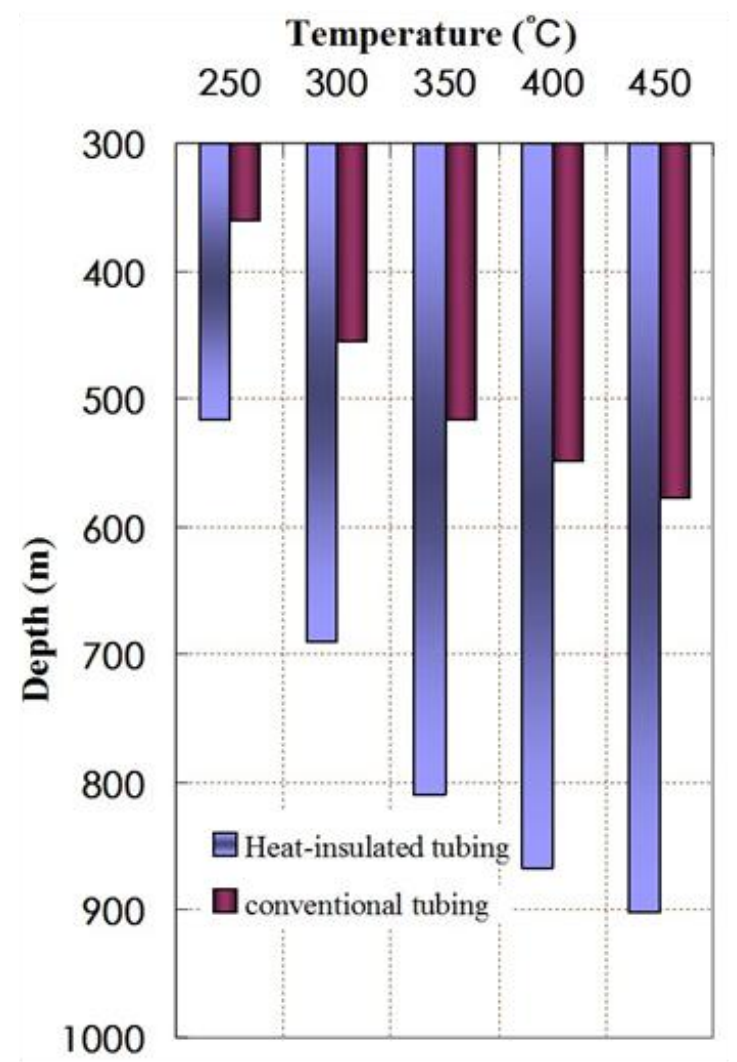

Figure 8. The depth the wet steam with quality of $40 \%$ and superheated steam can reach. match of the field production, the actual geological model is used to optimize the superheated steam injection, and the results are listed as follows (Figures 8, 9, and 10):

(1) At the stage of superheated steam CSS, the steam injection rate should reach 200 tons/day;

(2) The steam injection for the first cycle should reach 150 tons per perforated thickness;

(3) The optimum soak time is 13 days;

(4) The optimum liquid rate of the producer is $20 \sim 25$ tons/day;

(5) The optimum well pattern for superheated steam flooding is inverted nine spot, and the optimum well spacing is $100 \mathrm{~m}$;

(6) The production and injection ratio during superheated steam flooding should be 1.1 , so as to inhibit the influx of edge aquifer;

(7) Considering the effect of EOR by superheated steam, and arrangement of facilities for steamflooding, it is recommended that the super steam CSS should be converted to steamflooding after two cycles.

\section{Field scale development plan for superheated steam injection}

The North Кенкияк oil field is composed of Block I and II, and the target zone for superheated steam injection is юII . 132 and 169 wells are deployed in Blocks I and II. 


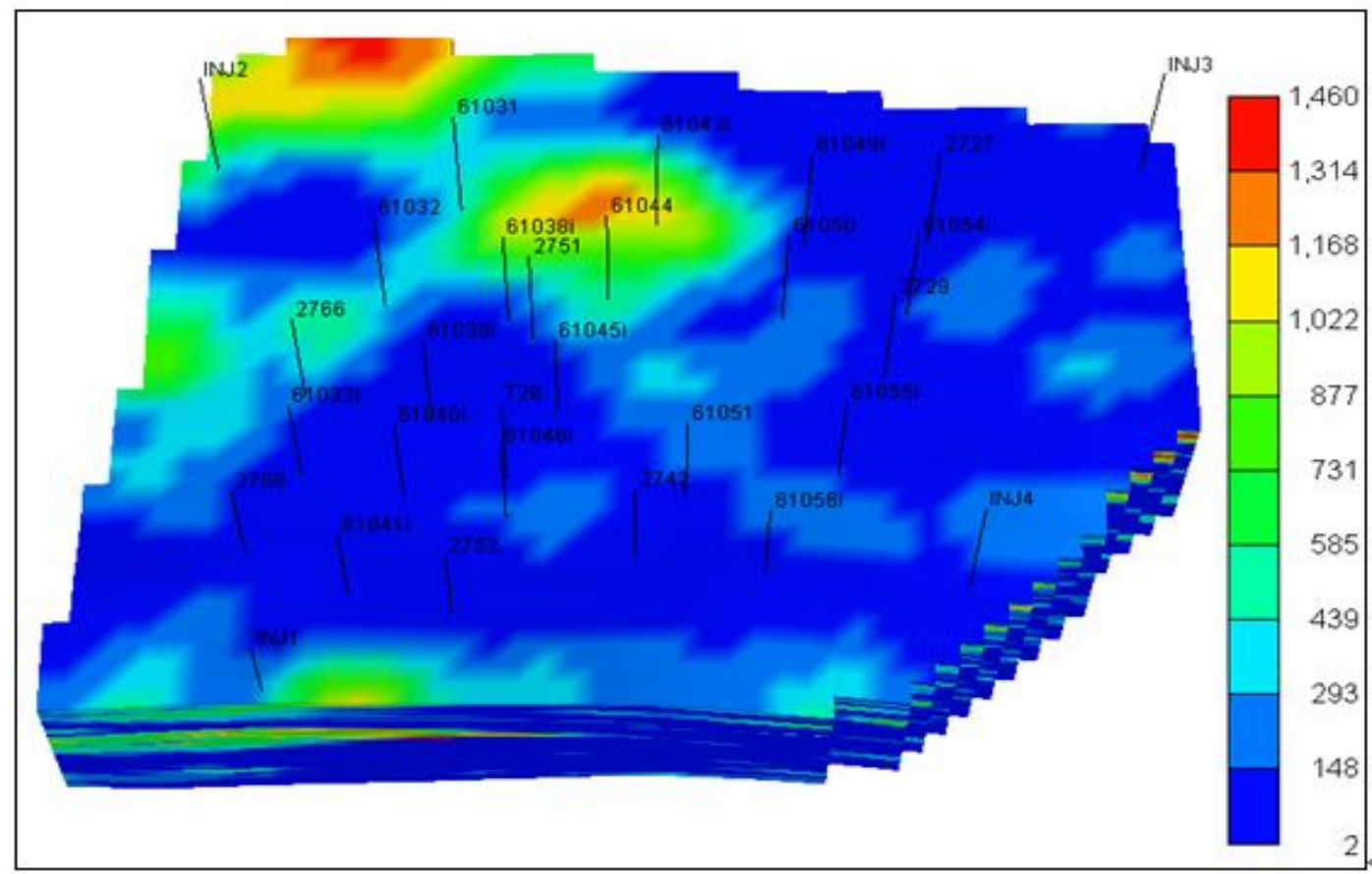

Figure 9. Typical well groups used for history match and parameters optimization for superheat steam injection.

Peak oil rate of new well and old well is designed to be 5 tons/day and 4 tons/day separately, therefore the production capacity for Blocks I and II is forecasted to be $0.173 \mathrm{MM}$ tons/year and $0.221 \mathrm{MM}$ tons/year.

Based on the well deployment for each block and the production capacity calculation for newly drilled and old wells, 6 cases of production scheme are forecasted and compared (Table 7).

Case 1: 1 cycle of CSS + Steam flooding;

Case 2: 2 cycles of CSS + Steam flooding;

Case 3: 3 cycles of CSS + Steam flooding;

Case 4: 1 cycles of CSS + Steam flooding + natural depletion;

Case 5: 2 cycles of CSS + Steam flooding + natural depletion;

Case 6: 3 cycles of CSS + Steam flooding + natural depletion;

\section{Economic evaluation and comparison for different cases}

The economic index for each case is calculated and compared, and the primary economic parameters are listed as follows:

(1) The evaluation time: 20 years (2009 2028),

(2) The discount rate: $12 \%$,
(3) Commodity rate of crude oil: $97 \%$,

(4) Oil price: 45USD/BBL,

(5) Drilling cost: $0.25 \mathrm{MM}$ USD/well,

(6) Surface construction cost: $0.3 \mathrm{MM}$ USD/well,

(7) Heat-insulated tubing cost: $0.1 \mathrm{MM}$ USD/well,

(8) Steam boiler cost: $0.55 \mathrm{MM}$ USD/well.

The economic evaluation results are listed in Table 8 . The economic evaluation results indicate that 2 cycles of CSS + Steamflooding followed by natural depletion is the best development scheme of superheated steam injection in the North Кенкияк oil field with the net profit 381.48 MM USD, and the IRR reaches $22.03 \%$, which indicates the weak economic risk.

\section{Conclusion}

Superheated steam stimulation has more the advantages compared with wet-steam injection, like rock wettability conversion, more specific heat enthalpy, specific heat volume, and larger latent heat of vaporization, etc. Numerical simulation showed that the superheated steam chamber existed within $3 \mathrm{~m}$ underground in the near wellbore area, therefore, the real superheated steam injection would be realized at the reservoir.

The cyclic oil production and cyclic oil steam ratio were much higher than the previous wet steam CSS in the pilot test. The cyclic period has been extended. The cyclic 


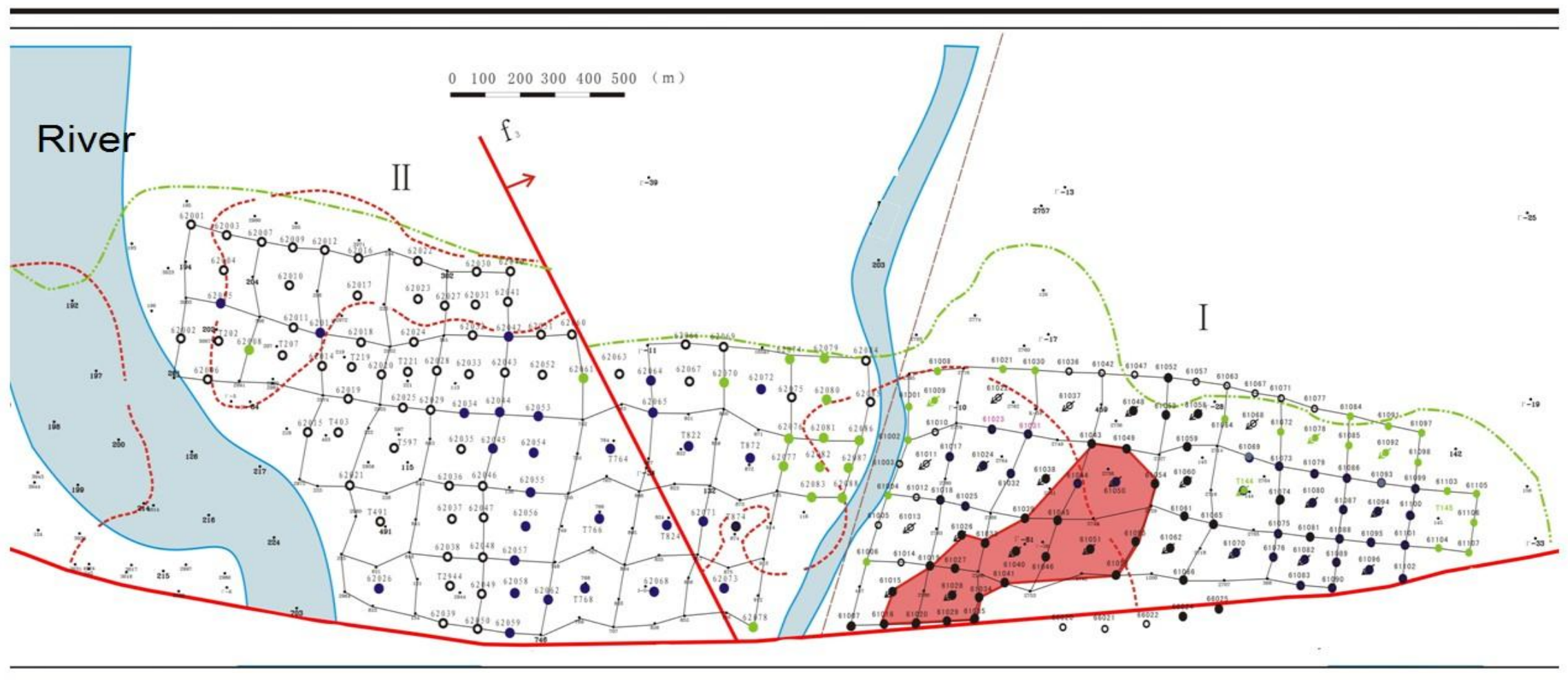

Figure 10. Field-scale well deployment for development.

Table 7. Production performance comparison for different cases.

\begin{tabular}{|c|c|c|c|c|c|c|}
\hline Case no. & $\begin{array}{c}\text { Economic production } \\
\text { time (year) } \\
\end{array}$ & $\begin{array}{c}\text { Plateau } \\
\text { duration (year) }\end{array}$ & $\begin{array}{l}\text { Peak oil production } \\
\text { (MMtons/year) }\end{array}$ & $\begin{array}{c}\text { Cumulative } \\
\text { steam injection (tons) }\end{array}$ & $\begin{array}{l}\text { Cumulative oil } \\
\text { production (tons) }\end{array}$ & $\begin{array}{c}\text { Oil recovery } \\
\text { factor (\%) }\end{array}$ \\
\hline 1 & 20 & 6 & 0.384 & 21.93 & 4.96 & 29.9 \\
\hline 2 & 18 & 6 & 0.363 & 19.01 & 4.57 & 27.5 \\
\hline 3 & 16 & 5 & 0.353 & 16.37 & 4.18 & 25.1 \\
\hline 4 & 20 & 6 & 0.384 & 16.99 & 4.63 & 27.9 \\
\hline 5 & 20 & 6 & 0.363 & 15.85 & 4.41 & 26.6 \\
\hline 6 & 20 & 5 & 0.353 & 15.25 & 4.22 & 25.4 \\
\hline
\end{tabular}


Table 8. Economic analysis comparison for different cases.

\begin{tabular}{|c|c|c|c|c|c|c|c|}
\hline \multirow{2}{*}{ Item } & \multirow{2}{*}{ Unit } & \multicolumn{6}{|c|}{ Case } \\
\hline & & 1 & 2 & 3 & 4 & 5 & 6 \\
\hline New investment in fixed assets & MM USD & 17.16 & 17.16 & 17.16 & 17.16 & 17.16 & 17.16 \\
\hline New investment for drilling & MM USD & 42 & 42 & 42 & 42 & 42 & 42 \\
\hline New investment for surface facilities & MM USD & 35.70 & 35.70 & 35.70 & 35.70 & 35.70 & 35.70 \\
\hline Sales income & MM USD & 1373.11 & 1265.90 & 1157.14 & 1281.47 & 1221.53 & 1169.08 \\
\hline Production costs and expenses & MM USD & 767.35 & 638.55 & 576.68 & 636.19 & 553.52 & 542.83 \\
\hline Operation cost & MM USD & 265.63 & 242.88 & 220.99 & 238.05 & 205.48 & 189.10 \\
\hline Net profit & MM USD & 340.52 & 361.69 & 335.81 & 363.13 & 381.48 & 356.31 \\
\hline IRR & $\%$ & $18.23 \%$ & $18.75 \%$ & $17.56 \%$ & $21.32 \%$ & $22.03 \%$ & $20.80 \%$ \\
\hline NPV (i=12\%) & MM USD & 101.63 & 108.83 & 82.38 & 120.12 & 124.23 & 98.62 \\
\hline Payback time & Year & 4.46 & 4.37 & 4.25 & 4.46 & 4.37 & 4.25 \\
\hline
\end{tabular}

produced water and steam ratio has been dropped. Field development plan is designed for 6 cases, and the scheme of 2 cycles of CSS + Steamflooding followed by natural depletion is the best regarding its best production and economic performance.

\section{ACKNOWLEDGEMENT}

The authors would like to thank the Department of Heavy Oil Recovery at the Research Institute of Petroleum Exploration, CNPC.

\section{REFERENCES}

Hossain A (1965). The displacement of oil from unconsolidated sand by high temperature fluid injection, M.S thesis, Texas A\&M University, College Station, TX.

Zhang X, Gao P, Yin D (2010). Investigation of Pressure Monitoring Methods for Xing1-2 Field, Daqing. In SPE Oil and Gas India Conference and Exhibition.

Jung K (1984). Unconventional Pilot Steam Drive, Tar V Sand,
Long Beach Unit, Wilmingtor Field, CA. SPE-12775. Wu S (2009). Utilizing Steam Injection to Improve Performance of Mature Waterflooding Resevoir. SPE-116549.

Zhao X, Zhong H, Gao P, Wu Y, Zhong H, Hasi B, Qian, Y (2010). Investigation of Steam Injection at Critical Condition and a Pilot Test in 119-52, Chao-601. In International Oil and Gas Conference and Exhibition in China.

Zhao X, Wu Y, Baiming Z, yu S, xianbao Z, Gao P (2011) Strategies to Conduct Steam Injection in Waterflooded Light Oil Reservoirand a Case in Fuyu Reservoir, Jilin. In SPE Middle East Oil and Gas Show and Conference.

Li X, Wu Y, Zhao X, Gao P, Qin Q, Yu M (2012). A CyclicSteam Injection in Fuyv Reservoir, Daqing. In SPE EOR Conference at Oil and Gas West Asia.

$\mathrm{Ge} J$, Ghassemi A (2008). "Analysis of Failure Potential around a Hydraulic Fracture in Jointed Rock," Presented in 42nd U.S. Rock Mechanics Symposium, San Francisco, California.

Falta RW, Pruess K, Javandel I, Witherspoon PA (1992). Numerical modeling of steam injection for the removal of nonaqueous phase liquids from the subsurface: 1 . Numerical formulation. Water Resour. Res. 28(2):433-449.

Willman BT, Valleroy VV, Runberg GW, Cornelius AJ, Powers LW (1961). 1537-G-Laboratory Studies of Oil Recovery by Steam Injection. J. Pet. Technol. 13(7):681-690.

Stone T, Malcolm J (1985). Simulation of a Large Steam-CO Co-Injection Experiment. J. Can. Pet. Technol. 24(6).
Gao P, Towler B (2011). Investigation of polymer and surfactant-polymer injections in South Slattery Minnelusa Reservoir, Wyoming. J. Pet. Explor. Prod. Technol. 1(1): 2331.

Gao P, Feng Y, Zhang X, LUO F (2009). Investigation of Cyclic Water Injection after Polymer Flood in Xing4-6 Field, Daqing. In Kuwait International Petroleum Conference and Exhibition. 